\title{
Integration of Biological and Fungicidal Alternatives for Controlling Foliar Diseases of Vegetables Under Greenhouse Conditions
}

\author{
M. M. Abdel-Kader ${ }^{*}$, Nehal S. El-Mougy, M. D. E. Aly, S. M. Lashin \\ Plant Pathology Department, National Research Centre, Giza, Egypt
}

\begin{abstract}
Evaluation the efficacy of bio-agents, resistance chemical inducers and/or thyme oil application as foliar spray against vegetables foliar diseases incidence was carried out in open greenhouse conditions. The tested bio-agents were Trichoderma harzianum, T. Viride, Bacillus subtilis, Pseudomonas flourescens and Saccharomyces serevisiae. Calcium chloride, Potassium monohydrogen phosphate, Potassium bicarbonate, Saccharin, Ascorbic acid, Chitosan and Humic \& Folic acid (mixture) as resistance chemical inducers were evaluated. The recorded foliar diseases, i.e. Powdery, Downy mildews of Cucumber, Cantaloupe and Pepper as well as Early, Late blights of Tomato were significantly reduced at all treatments either alone or in combinations comparing with untreated plants. Application with either T. harzianum and $B$. subtilis showed significant reduction in diseases incidence comparing with the other applied bio-agents. Under artificial infestation the most significant reduction in diseases incidence of tested vegetables were recorded in combined treatments of chemical inducers and S. serevisiae, i.e. (Chitosan + Thyme oil); (Chitosan + Saccharin); (Chitosan + Calcium chloride + S. serevisiae); (Chitosan + Potassium monohydrogen phosphate); (Saccharin + Potassium monohydrogen phosphate); (Humic $\&$ folic + Thyme oil) and (Chitosan + S. serevisiae) comparing with other applied treatments as well as untreated control. On the light of the present study it could be suggested that the usage of combined application of the bio-agents with resistance plant chemicals might be used as easily applied, safely and cost effective control methods against such foliar plant diseases.
\end{abstract}

Keywords Cucumber, Cantaloupe, Pepper, Tomato, Bio-Agents, Resistance Chemical Inducers, Powdery Mildew, Downy Mildew, Early Blight, Late Ablight

\section{Introduction}

Growing vegetables under protected cultivation is an important practice which approximately occupied about 60.000 feddans (24.000 Hectares) in Egypt[1]. Powdery and Downy mildews as well as Early and Late blights are the most serious foliar diseases attacked vegetables grown in plastic houses. Powdery mildew disease is one of the most serious plant diseases, causing large yield losses in a number of crops[2]. Also, late and early blights of tomato caused Phytophthora infestans and Alternaria solani were also recorded in growing greenhouse tomato[3,4].

In order to overcome such hazardous control strategies, scientists, researchers from all over the world paid more attention towards the development of alternative methods which are, by definition, safe in the environment, non-toxic to humans and animals and are rapidly biodegradable, one such strategy is use of Biocontrol agents (BCAs) to con trol

* Corresponding author:

mokh_nrc@yahoo.com (M.M. Abdel-Kader)

Published online at http://journal.sapub.org/ijaf

Copyright (C) 2012 Scientific \& Academic Publishing. All Rights Reserved fungal plant diseases.

Among the BCAs, species of the genus Trichoderma is most promising and effective biocontrol agnet. Trichoderma as antagonist controlling wide range of microbes[5], and their mechanism of mycoparasitism is much more complex, involves nutrient competition, hyperparasitism, antibiosis, space and cell wall degrading enzymes.

The biocontrol strains $P$. fluorescens PCL1751 and $P$. putida PCL1760 were effectively suppress Tomato foot and root rot under soil and hydroponic cultivation conditions[6]. Also, six Bacillus spp. isolated from the rhizosphere produced volatile metabolites that inhibited mycelia growth of Fusarium oxysporum in vitro[7]. They added that in soil treatment, the isolates had the highest effect in reducing the Fusarium wilt of onion.

A successful disease-control program could involve just a single practice, but the long term reduction of disease losses generally requires the application of several control measures. The best way to ensure success of a disease- management program is to use integrated disease-control measures[8]. Generally, IPM is regarded as the use of environmentally safe practices to reduce the disease incidence and development or use of multiple control tactics integrated into 
a single pest control strategy[9]. For example, different natural products, i.e., biocontrol agents, plant extracts and natural compounds were used as an IPM program to control powdery mildew of greenhouse crops[8,10]. Since economic thresholds have not been established for most plant pathogens, an IPM takes a somewhat different approach in plant disease control.

Salts have been previously studied as foliar applied control agents for powdery mildews on various horticultural crops. A recent review[11] discussed the use of different foliar applications including compost or plant extracts, surfactants, and inorganic salts. In Israel, research has demonstrated that the severity of powdery mildew on cucumber, grape, nectarine, mango, and rose can be reduced through foliar applications of phosphate and potassium salts[12-14]. Also, it was found that $\mathrm{KHCO}_{3}$, but not $\mathrm{NH}_{4} \mathrm{HCO}_{3}$ applications were effective in reducing the severity of powdery mildew on E. japonica and pumpkin[15,16]. In pot experiment, under artificial infestation with pathogenic fungus, application of sodium bicarbonate or calcium chloride significantly reduced the early blight incidence and severity [17]. They added that Calcium chloride proved higher efficacy for reducing both disease incidence and severity than that of sodium bicarbonate when applied either alone or combined with Saccharomyces cerevisiae. Phosphate foliar applications have been reported to induce local and systemic resistance to powdery mildew in cucumber $[16,18]$. Calcium administered to the plant through the nutrient feed has been reported to be important for resistance to bacterial wilt resistance in tomato[19].

These findings encouraged us to evaluate the potential use and the efficacy of foliar sprays of single or integrates of natural compounds as biological control ( $S$. cerevisiae), mineral salt $\left(\mathrm{CaCl}_{2}, \mathrm{~K}_{2} \mathrm{HPO}_{4}, \mathrm{CHCO}_{3}\right)$, antioxidant (ascorbic acid), resistance chemical inducers (Chitosan, Saccharin, Humic \& folic acids) and essential oil (Thyme) on grown vegetables to provide acceptable control level of powdery and downy mildews, early and late blights under greenhouse conditions.

Therefore, the main objective of the present study was foliar diseases control with eco-friendly environment by investigating the efficacy of foliar spray with some plant resistance inducers and/or bio-agents treatments under open greenhouse conditions.

\section{Materials and Methods}

\subsection{Plant materials}

Trasplants of Cucumber (cv. Alpha), Cantaloupe (cv. Yatherb 7), Tomato (cv. Castel Rock) and Pepper (cv. California) were used in the present study.

\subsection{Plant Resistance Inducers}

Calcium chloride, Potassium monohydrogen phosphate, Potassium bicarbonate, Saccharin, Ascorbic acid, Chitosan and Humic \& Folic acid (mixture) were purchased from Sigma-Aldrich. Meanwhile the essential oil Thyme (a.i. Thymol, 60\%) was obtained from Chemical Industrial Development Company (CID), Egypt.

\subsection{Bio-agents}

The tested antagonistic fungi were Trichoderma harzianum, T. Viride and the bacteria Bacillus subtilis, Pseudomonas flourescens and the yeast Saccharomyces serevisiae. These antagonists were isolated from the rhizosphere of cucumber, cantaloupe, tomato and pepper grown in plastic houses under protected cultivation systems and showing root rot disease symptoms[20]. The present bio-agents proved their antagonistic ability against the above mentioned pathogens under in vitro conditions.

\subsection{Greenhouse Experiments}

The efficacy of different plant resistance inducers, i.e. Calcium chloride, Thyme oil, Potassium monohydrogen phosphate, Potassium bicarbonate, Chitosan, Saccharin, Ascorbic acids and Humic \& Folic acids (A mixture) individually or in combination with the yeast $S$. serevisiae were evaluated against plant foliar diseases incidence in pot experiments were performed under open greenhouse conditions of Plant Pathology Dept., National Research Centre, Egypt.

Transplants of Cucumber, Cantaloupe, Tomato and Pepper were planted in natural loamy soil as three transplants per pot and five pots per replicates in each particular foliar treatment.

The applied treatments as foliar spray were as follows:

- Calcium chloride $2 \%(20 \mathrm{~g} / \mathrm{L})$.

- Calcium chloride $(2 \%)+$ S. serevisiae $\left(2 \times 10^{4} \mathrm{cfu} / \mathrm{mL}\right)$.

- Thyme oil $1 \%(10 \mathrm{ml} / \mathrm{L})$.

- Thyme oil $(1 \%)+S$. serevisiae $\left(2 \times 10^{4} \mathrm{cfu} / \mathrm{mL}\right)$.

- Potassium monohydrogen phosphate $(20 \mathrm{mM})$.

- Potassium monohydrogen phosphate $+S$. serevisiae $\left(2 \times 10^{4} \mathrm{cfu} / \mathrm{mL}\right)$.

- Potassium bicarbonate $(20 \mathrm{mM})$

- Potassium bicarbonate $(20 \mathrm{mM})+$ S. serevisiae $\left(2 \times 10^{4}\right.$ $\mathrm{cfu} / \mathrm{mL})$.

- Chitosan at the rate of $(0.05 \mathrm{mM})$.

- Chitosan $(0.05 \mathrm{mM})+$ S. serevisiae $\left(2 \times 10^{4} \mathrm{cfu} / \mathrm{mL}\right)$.

- Saccharin (3mM).

- Saccharin $(3 \mathrm{mM})+$ S. serevisiae $\left(2 \times 10^{4} \mathrm{cfu} / \mathrm{mL}\right)$.

- Ascorbic acid (20mM).

- Ascorbic acid $(20 \mathrm{mM})+$ S. serevisiae $\left(2 \times 10^{4} \mathrm{cfu} / \mathrm{mL}\right)$.

- Potassium bicarbonate $(20 \mathrm{mM})+$ Thyme oil $(1 \%)$.

- Chitosan $(0.05 \mathrm{mM})+$ Thyme oil $(1 \%)$.

- Chitosan $(0.05 \mathrm{mM})+$ Saccharin $(3 \mathrm{mM})$.

- Chitosan $(0.05 \mathrm{mM})+$ Calcium chloride $(2 \%)+$ S. serevisiae $\left(2 \times 10^{4} \mathrm{cfu} / \mathrm{mL}\right)$.

- Chitosan $(0.05 \mathrm{mM})+$ Potassium monohydrogen phosphate $(20 \mathrm{mM})$.

- Saccharin $(3 \mathrm{mM})+$ Potassium monohydrogen phosphate $(20 \mathrm{mM})$. 
- A mixture of Humic \& Folic acid (0.2\%) + Thyme oil $(1 \%)$

- Untreated control

Foliar spraying with tested chemical inducers and/or $S$. serevisiae were applied twice with two weeks intervals starting two weeks from transplanting. One week after the second inducers and/or $S$. serevisiae application, foliar artificial infestations with the casuals of Powdery and Downy mildews, Late blight was carried out as spraying of pathogen suspension as well as soil drench through soil irrigation with fungal suspension of early blight as stated before.

Another set of soil planted with tested vegetables transplants sprayed only with foliar diseases incidents was kept as control check treatment. Appearance of different foliar diseases incidence were recorded periodically and the average accumulated percentages were calculated after 60 days of transplanting, the experimental period.

Statistical analysis

All experiments were set up in a complete randomized design. One-way ANOVA was used to analyze differences between applied treatments and disease incidence. A general linear model option of the analysis system SAS[21] was used to perform the ANOVA. Duncan's multiple range test at $P<$ 0.05 level was used for means separation[22].

\section{Results and Discussion}

Data in Tables (1, 2 and 3) and Fig (1, 2 and 3) showed that all applied spray treatments of tested plant resistance inducers individually or in combination with $S$. serevisiae were able to reduce foliar diseases incidence of artificially infested with the diseases causal agents grown Cucumber, Cantaloupe, Tomato and Pepper grown in pots under open greenhouse conditions comparing with untreated check control.

Also, data revealed that the most significant reduction in diseases incidence of Cucumber, Cantaloupe and Pepper Powdery, Downy mildews and Tomato Early and Late blights in combined treatments of chemical inducers and $S$. serevisiae were (Chitosan + Thyme oil); (Chitosan + Saccharin); (Chitosan + Calcium chloride + S. serevisiae); (Chitosan + Potassium monohydrogen phosphate); (Saccharin + Potassium monohydrogen phosphate); (Humic \& folic + Thyme oil) and (Chitosan + S. serevisiae) comparing with other applied treatments as well as untreated control.

In this concern, data in Table (1) and Fig (1) showed that Powdery mildew disease incidence of Cucumber, Cantaloupe and Pepper was reduced at the average of 17.7, 15.5, $14.4,14.4,14.4,16.6$ and $17.7 \%$ in respective order to the above mentioned treatments comparing with $54.4 \%$ in untreated control plants. The highest reduction in Powdery mildew incidence was recorded between $13.3-20.0 \%$ in plants sprayed with treatments of (Chitosan + Thyme oil), (Chitosan + Saccharin), (Chitosan $+\mathrm{CaCl}_{2}+$ S. serevisiae), $\left(\right.$ Chitosan $\left.+\mathrm{K}_{2} \mathrm{HPO}_{4}\right),\left(\right.$ Saccharin $\left.+\mathrm{K}_{2} \mathrm{HPO}_{4}\right),($ Saccharin $+S$. serevisiae) and (Humic \& folic + Thyme oil). Meanwhile, powdery mildew incidence was recorded as 50.0, 43.0 and $40.0 \%$ of Cucumber, Cantaloupe and Pepper in untreated control treatments.

Similar trend was also observed concerning Downy mildew infection. Data in Table (2) and Fig (2) revealed that spraying Cucumber, Cantaloupe and Pepper with (Chitosan) and (chitosan $+S$. serevisiae) treatments caused reduction in Downy mildew disease incidence recorded as $26.6,20.0 \%$ \& 23.3, 20.0\% and 20.0, $13.3 \%$, respectively.

Moreover, Downy mildew incidence reduced as 23.3, 20.0\% \& 23.3, 20.0\% and 20.0, 13.3\% (Fig. 2) when Cucumber, Cantaloupe and Pepper sprayed with (Saccharin) and (Sacchrin + S. serevisiae) treatments, while Ascorbic acid and (Ascorbic acid $+S$. serevisiae) reduced disease incidence as 26.6, 20.0\% \& 26.6, 20.0\% and 23.3, 20.0\%, comparing with untreated control which recorded as 53.3, 40.0 and $46.6 \%$, in respective order to relevant tested vegetable plants.

Furthermore, it is interested to observe that the combined plant resistance induces treatments, (Chitosan + Thyme oil) and (Chitosan + Saccharin) reduced Downy mildew incidence to $16.6 \%$, while (Chitosan+ Calcium chloride $+S$. serevisiae); (Chitosan + Potassium monohydrogen phosphate); (Saccharin + Potassium monohydrogen phosphate) and (Humic \& folic (mixture) + Thyme oil) was 13.3\% comparing with untreated control 53.3, 40.0 and $13.3 \%$ comparing with untreated control 53.3, 40.0 and $46.6 \%$, in respective order to Cucumber, Cantaloupe and Pepper plants (Fig. 2).

Data in Table (3) and Fig (3) showed similar trend of tested chemical inducers individually or in combination and/or S. serevisiae and their efficacy against Early and Late blights incidence of Tomato. Presented data in Table (3) revealed an announced significant reduction in diseases incidence that complete inhibition (100\%) of both Early and Late blights was recorded when Tomato plants sprayed with $($ Saccharin + S. serevisiae $)$; (Chitosan + Thyme oil) ; (Chitosan + Saccharin) $;($ Chitosan + Calcium chloride + S. serevisiae); (Chitosan + Potassium monohydrogen phosphate); (Saccharin + Potassium monohydrogen phosphate) and (Humic \& folic (mixture) + Thyme oil).

The other tested treatments recorded early blight incidence as a range of $13.3-30.0 \%$ and $13.3-26.6 \%$ for late blight comparing with untreated control which recorded as $33.3 \%$ for both diseases (Fig. 3). The use of plant resistance inducers in combination with bio-agents was subjected to evaluation in many reports. In this regards, an interesting alternative to fungicide application for plant disease control involves the use of some organic and inorganic salts with antimicrobial properties generally used in food processing and preservation.

Selected organic and inorganic salts are active antimicrobial agents and have been widely used in the food industry. Many of these salts are effective against a range of microorganisms; most of them have low mammalian toxicity and therefore have potential for postharvest disease control. Salt treatments can inhibit plant pathogens or suppress my- 
cotoxin production[23,24]. Also,[25] found that from field experiments, that spraying cantaloupe plants three times with fungicides in alternation with another three sprays with any of calcium chloride or salicylic acid resulted in significant reduction in the disease severity with significant increase in the fruit yield when compared with unsprayed (check) plants.

Furthermore, Sodium and ammonium bicarbonate were shown to inhibit fungal pathogens of fruits, field crops, vegetables, and ornamentals[15,26]. Also, sodium bicarbonate applied at room temperature at 2 to $4 \%$ reduced blue mold caused by Penicillium italicum in Citrus fruits[27]. Moreover, beneficial effect of two food additives, ammonium molybdate and sodium bicarbonate on antagonistic yeasts for control of brown rot in sweet cherry was evaluated [28]. They found that application of additives improved biocontrol of brown rot on sweet cherry fruit under various storage conditions. It is postulated that the enhancement of disease control is directly because of the inhibitory effects of additives on pathogen growth, and indirectly because of the relatively little influence of additives on the growth of antagonistic yeasts.

Table 1. Effect of spraying antagonistic bio-agents and chemical inducers against Powdery mildew diseases under open greenhouse conditions

\begin{tabular}{|c|c|c|c|c|}
\hline \multirow{3}{*}{ Treatment * } & \multicolumn{4}{|c|}{ Vegetables foliar diseases incidence (\%) } \\
\hline & \multicolumn{4}{|c|}{ Powdery mildew } \\
\hline & Cucumber & Cantaloupe & Pepper & Mean \\
\hline $\mathrm{CaCl} 2$ & $40.0 \mathrm{~b}$ & $36.6 \mathrm{~b}$ & $33.3 \mathrm{~b}$ & 36.6 \\
\hline CaCl2+ S. serevisiae & $36.6 \mathrm{c}$ & $30.0 \mathrm{c}$ & $30.0 \mathrm{c}$ & 32.2 \\
\hline Thyme oil & $30.0 \mathrm{~d}$ & $33.3 \mathrm{bc}$ & $30.0 \mathrm{c}$ & 31.1 \\
\hline Thyme + S. serevisiae & $26.6 \mathrm{e}$ & $26.6 \mathrm{~cd}$ & $23.3 \mathrm{e}$ & 25.5 \\
\hline K2HPO4 & $33.3 \mathrm{~cd}$ & $36.6 \mathrm{~b}$ & $26.6 \mathrm{~cd}$ & 32.1 \\
\hline K2HPO4 + S. serevisiae & $30.0 \mathrm{~d}$ & $26.6 \mathrm{~cd}$ & $20.0 \mathrm{f}$ & 25.5 \\
\hline CHCO3 & $43.3 \mathrm{ab}$ & $36.6 \mathrm{~b}$ & $23.3 \mathrm{e}$ & 34.4 \\
\hline CHCO3 + S. serevisiae & $40.0 \mathrm{~b}$ & $30.0 \mathrm{c}$ & $20.0 \mathrm{f}$ & 30.0 \\
\hline Chitosan & $23.3 \mathrm{ef}$ & $26.6 \mathrm{~cd}$ & $20.0 \mathrm{f}$ & 23.3 \\
\hline Chitosan + S. serevisiae & $16.6 \mathrm{fg}$ & $20.0 \mathrm{e}$ & $16.6 \mathrm{fg}$ & 17.7 \\
\hline Saccharin & $36.6 \mathrm{c}$ & $26.6 \mathrm{~cd}$ & $20.0 \mathrm{f}$ & 27.7 \\
\hline Saccharin + S. serevisiae & $30.0 \mathrm{~d}$ & $20.0 \mathrm{e}$ & $13.3 \mathrm{~g}$ & 21.1 \\
\hline Ascorbic acid & $33.3 \mathrm{~cd}$ & $30.0 \mathrm{c}$ & $23.3 \mathrm{e}$ & 28.8 \\
\hline Ascorbic acid + S. serevisiae & $26.6 \mathrm{e}$ & $23.3 \mathrm{de}$ & $20.0 \mathrm{f}$ & 23.3 \\
\hline CHCO3 + Thyme oil & $26.6 \mathrm{e}$ & $30.0 \mathrm{c}$ & $20.0 \mathrm{f}$ & 25.5 \\
\hline Chitosan + Thyme oil & $16.6 \mathrm{fg}$ & $20.0 \mathrm{e}$ & $16.6 \mathrm{fg}$ & 17.7 \\
\hline Chitosan + Saccharin & $13.3 \mathrm{~g}$ & $16.6 \mathrm{f}$ & $16.6 \mathrm{fg}$ & 15.5 \\
\hline Chitosan+CaCl2+S. serevisiae & $13.3 \mathrm{~g}$ & $16.6 \mathrm{f}$ & $13.3 \mathrm{~g}$ & 14.4 \\
\hline Chitosan + K2HPO4 & $16.6 \mathrm{fg}$ & $13.3 \mathrm{~g}$ & $13.3 \mathrm{~g}$ & 14.4 \\
\hline Saccharin + K2HPO4 & $16.6 \mathrm{fg}$ & $13.3 \mathrm{~g}$ & $13.3 \mathrm{~g}$ & 14.4 \\
\hline Humic \& folic + Thyme oil & $20.0 \mathrm{f}$ & $16.6 \mathrm{f}$ & $13.3 \mathrm{~g}$ & 16.6 \\
\hline Control & $50.0 \mathrm{a}$ & $43.3 \mathrm{a}$ & $40.0 \mathrm{a}$ & 54.4 \\
\hline
\end{tabular}

Mean values within columns for each host plant followed by the same letter are not significantly different $(\mathrm{P} \leq 0.05)$

${ }^{*}$ Calcium chloride $=\mathrm{Cacl}_{2}$; Potassium mono-hydrogen phosphate $=\mathrm{K}_{2} \mathrm{HPO}_{4}$; Potassium bicarbonate $=\mathrm{CHCO}_{3}$ and $\mathrm{Saccharin}_{=} \mathrm{C}_{7} \mathrm{H}_{4} \mathrm{NNaO}_{3} \mathrm{~S}$

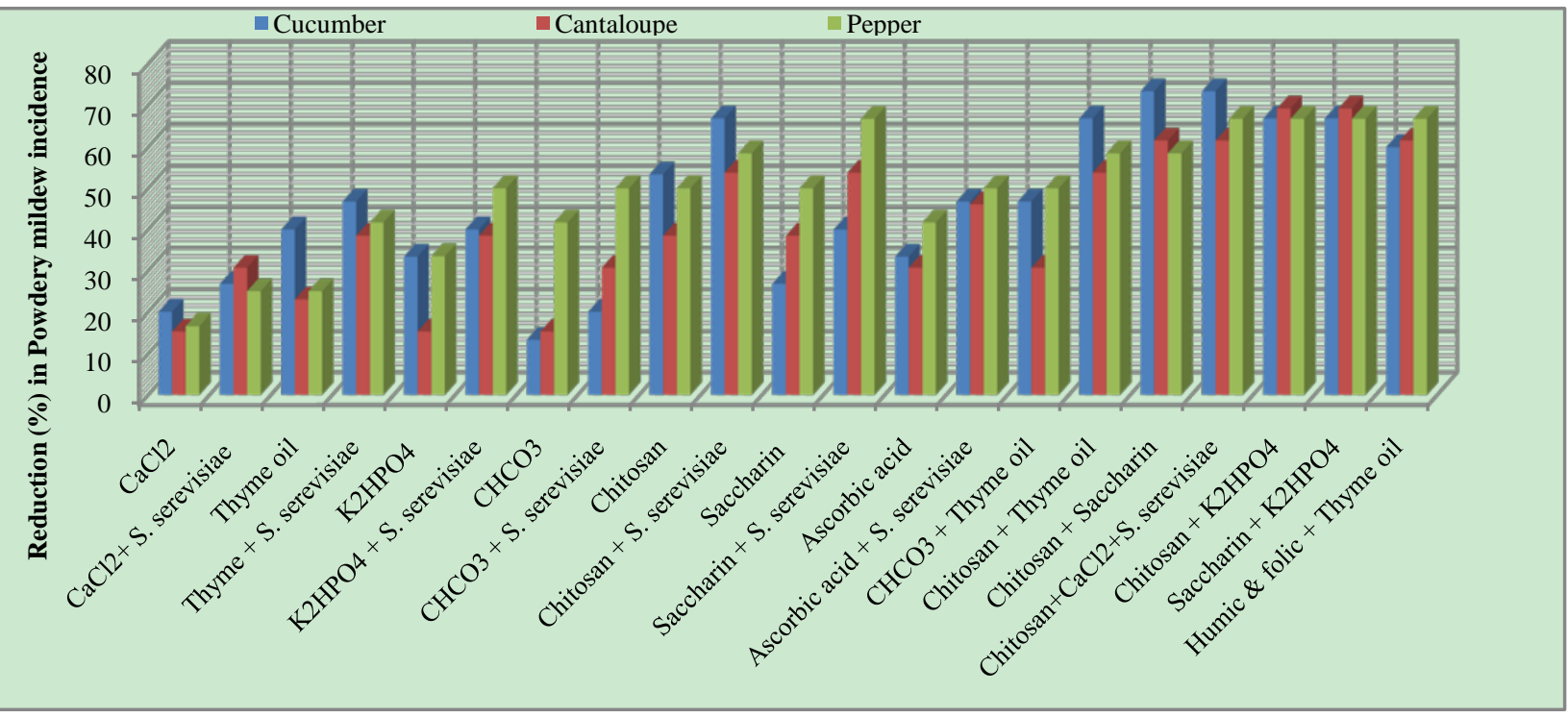

Figure 1. Reduction in Powdery mildew disease in response to spraying antagonistic bio-agents and/or plant resistance inducers under open greenhouse conditions 
Table 2. Effect of spraying antagonistic bio-agents and chemical inducers against Downy mildew diseases Under open greenhouse conditions

\begin{tabular}{|c|c|c|c|c|}
\hline \multirow{3}{*}{ Treatment $^{*}$} & \multicolumn{4}{|c|}{ Vegetables foliar diseases incidence (\%) } \\
\hline & \multicolumn{4}{|c|}{ Downy mildew } \\
\hline & Cucumber & Cantaloupe & Pepper & Mean \\
\hline $\mathrm{CaCl}_{2}$ & $43.3 \mathrm{~b}$ & $40.0 \mathrm{a}$ & $40.0 \mathrm{ab}$ & 41.0 \\
\hline $\mathrm{CaCl}_{2}+$ S. serevisiae & $36.6 \mathrm{c}$ & $33.3 \mathrm{~b}$ & $36.6 \mathrm{~b}$ & 35.5 \\
\hline Thyme oil & $36.6 \mathrm{c}$ & $33.3 \mathrm{~b}$ & $33.3 \mathrm{bc}$ & 34.4 \\
\hline Thyme + S. serevisiae & $30.0 \mathrm{~cd}$ & $30.0 \mathrm{bc}$ & $30.0 \mathrm{c}$ & 30.0 \\
\hline $\mathrm{K}_{2} \mathrm{HPO}_{4}$ & $33.3 \mathrm{~cd}$ & $30.0 \mathrm{bc}$ & $30.0 \mathrm{c}$ & 31.1 \\
\hline $\mathrm{K}_{2} \mathrm{HPO}_{4}+$ S. serevisiae & $26.6 \mathrm{~d}$ & $26.6 \mathrm{c}$ & $26.6 \mathrm{~cd}$ & 26.6 \\
\hline $\mathrm{CHCO}_{3}$ & $30.0 \mathrm{~cd}$ & $26.6 \mathrm{c}$ & $20.0 \mathrm{e}$ & 25.5 \\
\hline $\mathrm{CHCO}_{3}+$ S. serevisiae & $23.3 \mathrm{ef}$ & $20.0 \mathrm{e}$ & 16.6 ef & 19.9 \\
\hline Chitosan & 26.6 e & $23.3 \mathrm{~cd}$ & $20.0 \mathrm{e}$ & 23.3 \\
\hline Chitosan + S. serevisiae & $20.0 \mathrm{f}$ & 20.0 e & $13.3 \mathrm{f}$ & 17.7 \\
\hline Saccharin & 23.3 ef & $23.3 \mathrm{~cd}$ & $20.0 \mathrm{e}$ & 22.2 \\
\hline Saccharin + S. serevisiae & $20.0 \mathrm{f}$ & $20.0 \mathrm{e}$ & $13.3 \mathrm{f}$ & 17.7 \\
\hline Ascorbic acid & $26.6 \mathrm{e}$ & $26.6 \mathrm{c}$ & $23.3 \mathrm{de}$ & 25.5 \\
\hline Ascorbic acid + S. serevisiae & $20.0 \mathrm{f}$ & $20.0 \mathrm{e}$ & $20.0 \mathrm{e}$ & 20.0 \\
\hline $\mathrm{CHCO}_{3}+$ Thyme oil & 23.3 ef & $20.0 \mathrm{e}$ & $20.0 \mathrm{e}$ & 21.1 \\
\hline Chitosan + Thyme oil & 16.6 ef & 16.6 ef & 16.6 ef & 16.6 \\
\hline Chitosan + Saccharin & $16.6 \mathrm{~g}$ & 16.6 ef & 16.6 ef & 16.6 \\
\hline Chitosan $+\mathrm{CaCl}_{2}+\mathrm{S}$. serevisiae & $13.3 \mathrm{~g}$ & $13.3 \mathrm{~g}$ & $13.3 \mathrm{f}$ & 13.3 \\
\hline Chitosan $+\mathrm{K}_{2} \mathrm{HPO}_{4}$ & $13.3 \mathrm{~g}$ & $13.3 \mathrm{~g}$ & $13.3 \mathrm{f}$ & 13.3 \\
\hline Saccharin $+\mathrm{K}_{2} \mathrm{HPO}_{4}$ & $13.3 \mathrm{~g}$ & $13.3 \mathrm{~g}$ & $13.3 \mathrm{f}$ & 13.3 \\
\hline Humic \& folic + Thyme oil & $13.3 \mathrm{~g}$ & $13.3 \mathrm{~g}$ & $13.3 \mathrm{f}$ & 13.3 \\
\hline Control & 53.3 a & $40.0 \mathrm{a}$ & $46.6 \mathrm{a}$ & 46.6 \\
\hline
\end{tabular}

Mean values within columns for each host plant followed by the same letter are not significantly different $(\mathrm{P} \leq 0.05)$.

${ }^{*}$ Calcium chloride $=\mathrm{Cacl}_{2}$; Potassium mono-hydrogen phosphate $=\mathrm{K}_{2} \mathrm{HPO}_{4}$; Potassium bicarbonate $=\mathrm{CHCO}_{3}$ and Saccharin $=\mathrm{C}_{7} \mathrm{H}_{4} \mathrm{NNaO}_{3} \mathrm{~S}$

Table 3. Effect of spraying antagonistic bio-agents and plant resistance inducers against Tomato Early and Late blights diseases under open greenhouse conditions

\begin{tabular}{|c|c|c|c|}
\hline \multirow{3}{*}{ Treatment ${ }^{*}$} & \multicolumn{3}{|c|}{ Vegetables foliar diseases incidence (\%) } \\
\hline & \multicolumn{3}{|c|}{ Tomato } \\
\hline & Early blight & Late blight & Mean \\
\hline $\mathrm{CaCl}_{2}$ & $30.0 \mathrm{ab}$ & $26.6 \mathrm{~b}$ & 28.3 \\
\hline $\mathrm{CaCl}_{2}+$ S. serevisiae & $26.6 \mathrm{~b}$ & $20.0 \mathrm{c}$ & 23.3 \\
\hline Thyme oil & $23.3 \mathrm{~b}$ & $23.3 \mathrm{bc}$ & 23.3 \\
\hline Thyme + S. serevisiae & $20.0 \mathrm{bc}$ & $20.0 \mathrm{c}$ & 20.0 \\
\hline $\mathrm{K}_{2} \mathrm{HPO}_{4}$ & $16.6 \mathrm{~d}$ & $20.0 \mathrm{c}$ & 18.3 \\
\hline $\mathrm{K}_{2} \mathrm{HPO}_{4}+$ S. serevisiae & $13.3 \mathrm{~d}$ & $16.6 \mathrm{~d}$ & 14.9 \\
\hline $\mathrm{CHCO}_{3}$ & $20.0 \mathrm{bc}$ & $20.0 \mathrm{c}$ & 20.0 \\
\hline $\mathrm{CHCO}_{3}+$ S. serevisiae & $16.6 \mathrm{~d}$ & $13.3 \mathrm{e}$ & 14.9 \\
\hline Chitosan & $16.6 \mathrm{~d}$ & $13.3 \mathrm{e}$ & 14.9 \\
\hline Chitosan + S. serevisiae & $13.3 \mathrm{~d}$ & $0.0 \mathrm{f}$ & 6.6 \\
\hline Saccharin & $13.3 \mathrm{~d}$ & $13.3 \mathrm{e}$ & 13.3 \\
\hline Saccharin + S. serevisiae & $0.0 \mathrm{e}$ & $0.0 \mathrm{f}$ & 0.0 \\
\hline Ascorbic acid & $20.0 \mathrm{bc}$ & $16.6 \mathrm{~d}$ & 18.3 \\
\hline Ascorbic acid $+S$. serevisiae & $16.6 \mathrm{~d}$ & $13.3 \mathrm{e}$ & 14.9 \\
\hline $\mathrm{CHCO}_{3}+$ Thyme oil & $16.6 \mathrm{~d}$ & $13.3 \mathrm{e}$ & 14.9 \\
\hline Chitosan + Thyme oil & $0.0 \mathrm{e}$ & $0.0 \mathrm{f}$ & 0.0 \\
\hline Chitosan + Saccharin & $0.0 \mathrm{e}$ & $0.0 \mathrm{f}$ & 0.0 \\
\hline Chitosan $+\mathrm{CaCl}_{2}+$ S. serevisiae & $0.0 \mathrm{e}$ & $0.0 \mathrm{f}$ & 0.0 \\
\hline Chitosan $+\mathrm{K}_{2} \mathrm{HPO}_{4}$ & $0.0 \mathrm{e}$ & $0.0 \mathrm{f}$ & 0.0 \\
\hline Saccharin $+\mathrm{K}_{2} \mathrm{HPO}_{4}$ & $0.0 \mathrm{e}$ & $0.0 \mathrm{f}$ & 0.0 \\
\hline Humic \& folic + Thyme oil & $0.0 \mathrm{e}$ & $0.0 \mathrm{f}$ & 0.0 \\
\hline Control & $33.3 \mathrm{a}$ & $33.3 \mathrm{a}$ & 33.3 \\
\hline
\end{tabular}

Mean values within columns for each host plant followed by the same letter are not significantly different $(\mathrm{P} \leq 0.05)$.

${ }^{*}$ Calcium chloride $=\mathrm{Cacl}_{2}$; Potassium mono-hydrogen phosphate $=\mathrm{K}_{2} \mathrm{HPO}_{4} ;$ Potassium bicarbonate $=\mathrm{CHCO}_{3}$ and $\mathrm{Saccharin}=\mathrm{C}_{7} \mathrm{H} 4 \mathrm{NNaO}_{3} \mathrm{~S}$ 


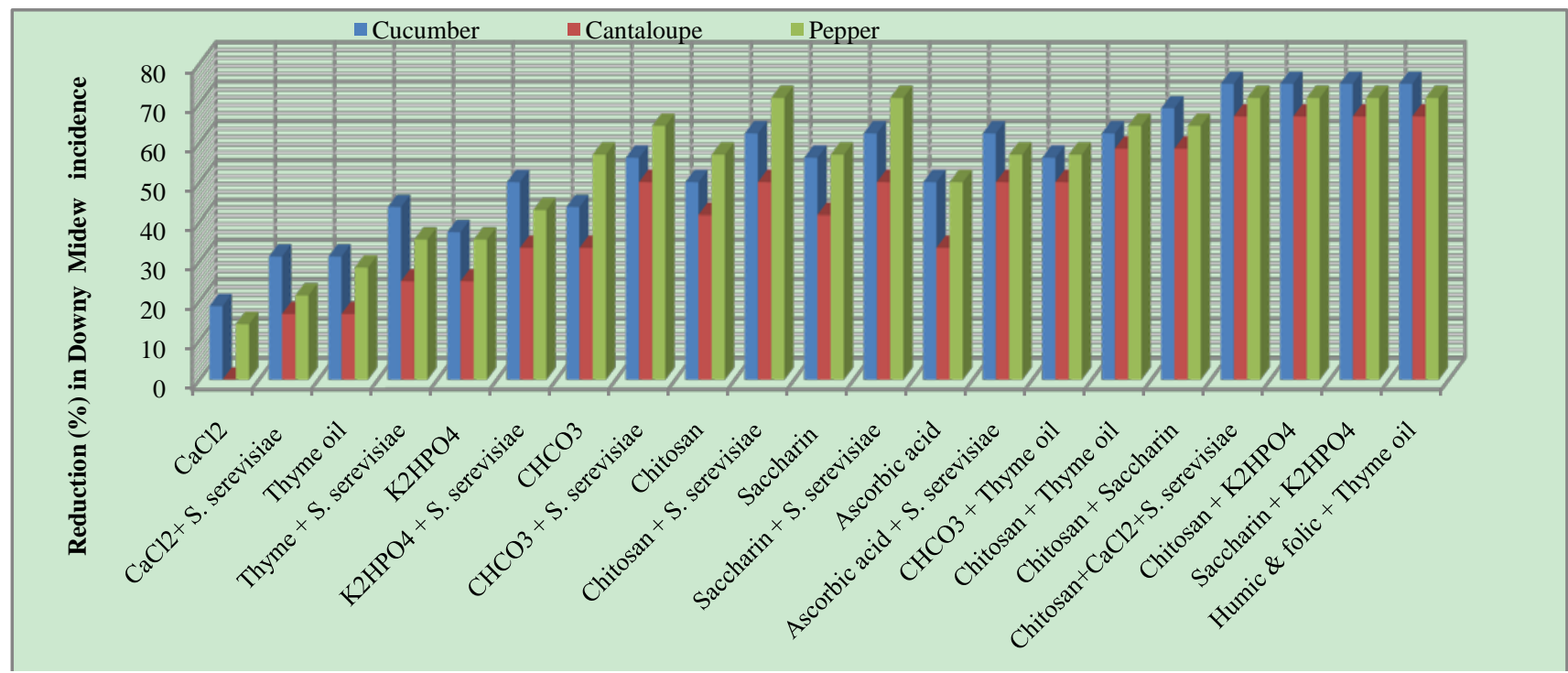

Figure 2. Reduction in Downy mildew disease incidence in response to spraying antagonistic bio-agents and /or plant resistance inducers under open greenhouse conditions

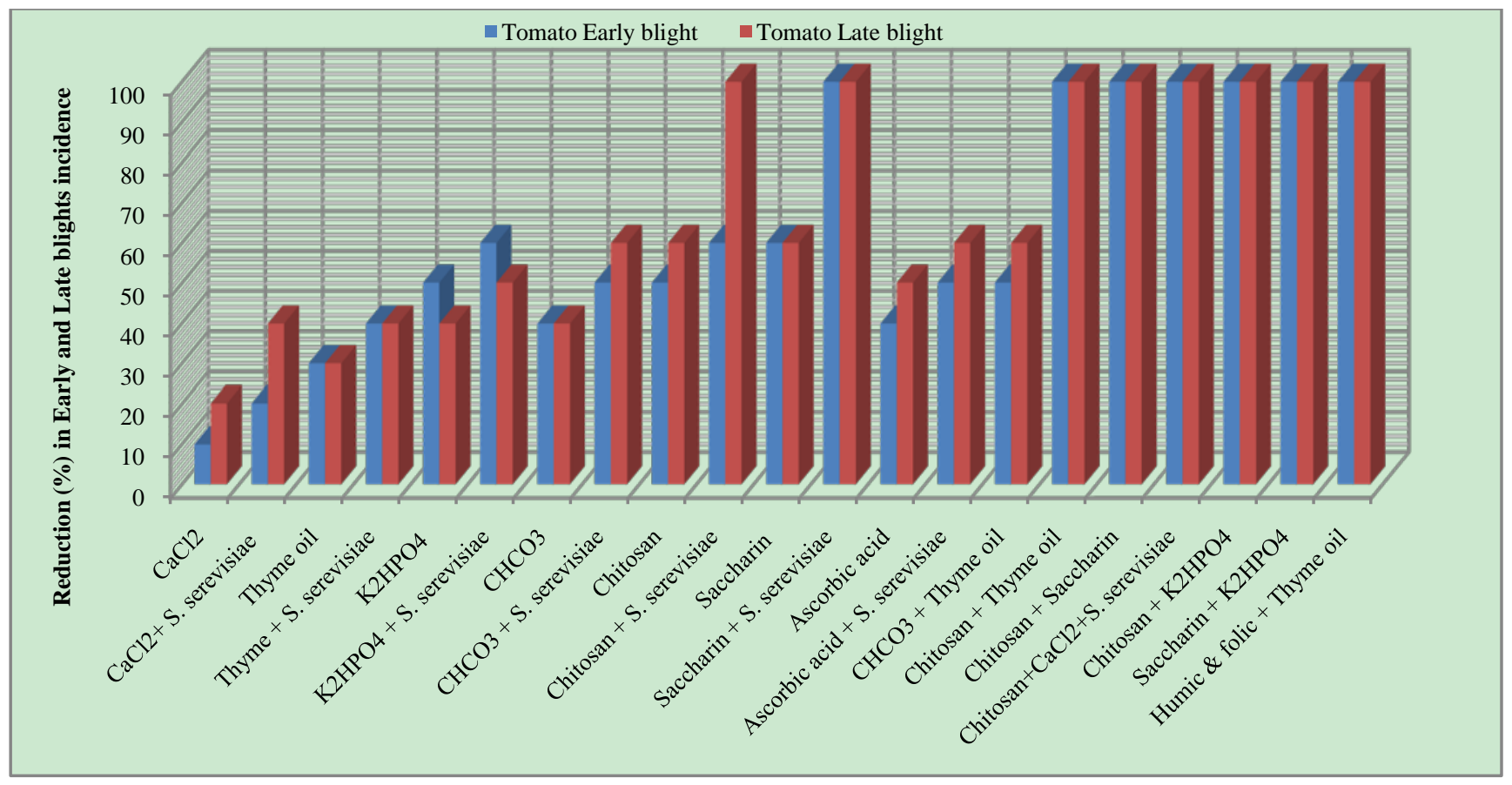

Figure 3. Reduction in Tomato Early and Late blights diseases incidence in response to spraying antagonistic bio-agents and /or plant resistance inducers under open greenhouse conditions

In vitro activity of sodium carbonate salt against germinated or ungerminated spores of $P$. italicum and $P$. digitatum was higher than that of bicarbonate salt, although their efficacy was similar in vivo[29]. In vitro activity of sodium carbonate salt against germinated or ungerminated spores of $P$. italicum and $P$. digitatum was higher than that of bicarbonate salt, although their efficacy was similar in vivo[29]. They suggested that the original toxicity of the treating sodium bicarbonate solution to the spores is altered by interactions in wounds with constituents of the rind and the relatively high $\mathrm{pH}$ of these solutions has been proposed to be the mode of action. The use of sodium bicarbonate alone to control postharvest decays of fruit has its limitations[27], but it can be combined with other alternative treatments to synthetic fungicides, resulting in the control that is superior to individual treatments alone. For example, sodium bicarbonate was successfully used in combination with bacterial and yeasts biocontrol agents to enhance control of postharvest decays on citrus, pome, and stone fruits[29-31]. These reports are clearly demonstrated in the present study and show that the application of $S$. cerevisiae enhanced the control of foliar vegetables diseases when combined with either sodium bicarbonate or calcium chloride spray. It was reported that $S$. cerevisiae required an inoculum of $10^{5} \mathrm{cfu} / \mathrm{g}$ to inhibit the growth of Penicillium roqueforti in non-sterile high-moisture wheat grains[32]. In this concern inoculum 
used in the present work was more effective where it reached $\left(2 \times 10^{4} \mathrm{cfu} / \mathrm{mL}\right)$.

Many researchers have shown that calcium plays an important role in the inhibition of postharvest decay of fruits $[33,35]$, and in enhancing the efficacy of postharvest biocontrol agents[34,36]. Postharvest calcium treatment of apples provided broad-spectrum protection against the postharvest pathogens of Penicillium expansum and Botrytis cinerea[37]. The addition of $\mathrm{CaCl}_{2}(2 \% \mathrm{w} / \mathrm{v})$ to the formulation of the yeast biocontrol agent, Candida oleophila, enhanced the ability of this yeast to protect apples against postharvest decay[36]. The efficacy of controlling grey mould and blue mould rots in apples was enhanced when Trichosporon sp. was applied in the presence of $\mathrm{CaCl}_{2}(2 \%$ $\mathrm{w} / \mathrm{v}$ ) in an aqueous suspension[38]. In the present study calcium chloride application either alone or combined with other plant rsistance inducers and/or S. serevisiae was able to reduce foliar disease incidence. In this concern, the applications of Ca contributed to reducing the intensity of white mold on dry beans, but did not affect bean yield in a soil with high amounts of this nutrient. In the USA, found tht foliar-applied Ca was found to enhance both disease control and dry bean yield[39]. The author suggested that Ca may be a nutritional supplement that increases plant resistance to white mold. Nutritional effect is particularly noticeable in the case of Ca compounds with high water solubility, like $\mathrm{CaCl}_{2}$. It has been suggested that plants resistant to S. sclerotiorum have higher Ca levels than susceptible ones[40]. Also,[41] recorded that incidence and severity of white mold on dry bean were significantly reduced with application of calcium chloride and calcium silicate.

Saccharin and Chitosan had shown effective influence, in the present work, for reducing foliar diseases when sprayed either alone or in combined treatment. These records were confirmed with previous reports. Saccharin is a metabolite of probenazole and has also been found to induce resistance in a number of host-pathogen systems, including tobacco mosaic virus[42], barley Blumeria graminis f. sp. hordei[44] and broad bean Uromyces fabae[43]. In barley, saccharin did not induce defenses directly, but rather primed plants against infection by the powdery mildew fungus[44]. Also, Saccharin treatment provided systemic protection of barley against the leaf scald pathogen $R$. secalis. This agrees with previous work which showed protection of barley against powdery mildew [44], broad bean against rust[43] and tobacco against TMV [42]. These data also confirm earlier studies which showed that saccharin treatment primed CAD activity in barley against subsequent challenge with powdery mildew[44]. As for Chiosan, in recent years, the importance of chitosaccharides as plant growth promoting and disease control agents has been emphasized[45,46]. CHN ( $\beta-1-4$ linked $N$ - glucosamine) has been shown to induce defense responses in different plants[47,48]. Chitosan oligomers was found to induce defense responses in grapevine leaves, as evidenced by an accumulation of stilbene phytoalexins, trans- and cis-resveratrol, $\varepsilon$-viniferins, and piceids, and a stimulation of chitinase and $\beta$-1,3-glucanase activities[46]. Furthermore, the combination of Chitosan and $\mathrm{CuSO}_{4}$ increased phytoalexin production. This elicitor capacity of Chitosan and/or $\mathrm{CuSO}_{4}$ appeared to be associated with an induced protection of grapevine leaves against gray mold and downy mildew diseases. Furthermore,[49] recorded that chitosan/copper complex retained a presence on the potato leaf surface late and early blights where infection by either $A$. solani or $P$. infestans occurs. Moreover, Chitosan could enhance the accumulation of pathogenesis related-proteins such as ss-1,3-glucanase, chninase and PR14 in treated and upper untreated tomato leaves[50]. The studies with chitosan against tomato late blight suggested that chitosan displays dual effects: (a) direct interference in developmental stages of $P$. infestans and (b) by lesion formation, leading to disease resistance mechanisms. Moreover, several workers suggested two different mechanisms of chitosan molecule and target microorganism interaction: the first is the adsorption of chitosans to cell walls leading to the cell wall covering, membrane disruption and cell leakage; the second is the penetration of chitosans into living cells leading to the inhibition of various enzymes and interference with the synthesis of mRNA and proteins[51-53].

On the other hand, Humic acid is a suspension, based on potassium humates, which can be applied successfully in many areas of plant production as a plant growth stimulant or soil conditioner for enhancing natural resistance against plant diseases and pests, stimulation plant growth through increased cell division, as well as optimized uptake of nutrients and water[54]. Furthermore, [55], reported that bean plants treated with humic acid induced resistance against root rot and Alternaria leaf spot. The role of Humic acid in overcoming the harmful effects of chocolate spot and rust diseases in faba bean plant may be due to the increase in chitinase activity [55] and stimulation plant growth through increased cell division, as well as optimized uptake of nutrients and water[56,57] also, regulate hormone level, improve plant growth and enhance stress tolerance[58].

Humic acid is a suspension, based on potassium humates, which can be applied successfully in many areas of plant production as a plant growth stimulant or soil conditioner for enhancing natural resistance against plant diseases and pests [54] which consequently increase yield of plant. Foliar application of Humic acid consistently enhanced antioxidants such as á-tocopherol, â-carotene, superoxide dismutases, and ascorbic acid concentrations in turf grass species[59].These antioxidant may play a role in the regulation of plant development, flowering and chilling of disease resistance [60-62]. The effect of spray application with Ascorbic acid as antioxidant against foliar diseases was also observed in the present study. Under artificial infestation with Powdery and Downy mildews pathogens, Cucumber; Cantaloupe and Pepper plants expressed disease incidence as 54.4 and $46.6 \%$ in medium, meanwhile when sprayed with Ascorbic acid only or combined with $S$. cerevisiae revealed diseases infection estimated as 28.8, 25.5\%, and 23.3 and $20.0 \%$, in respective order. Similar effect was also recorded concerning Tomato Early and Late blight which recorded as 18.3 and 
14.9\% in Ascorbic acid only or combined with S. cerevisiae treatments comparing with $33.3 \%$ in control treatment, respectively.

Essential oils as natural alternatives that are user friendly and demonstrate low toxicity to humans are desirable to be tested either alone or in combination in the present work. Thyme oil applied alone or in combination showed effective reduction in foliar diseases incidence more than 50\%, moreover complete reduction in Tomato Early and Late blights was recorded in Thyme oil combined with either $S$. cerevisiae or Humic \& Folic acid (a mixture). In this regards, several investigators reported the antifungal effect of essential oils. Also, Thyme and Egyptian geranium oils are considered antimycotic natural compounds may be useful for inhibition of mold fungi on wood in service or during storage of building materials[63]. Moreover, [64] had the first report on the use of Thymol for controlling a plant disease under field conditions, which indicated that this compound provided effective control of bacterial wilt on susceptible tomato cultivars. Also, Thymol has been reported to have fungicidal activities and fumigation with thymol has been used for control of postharvest fungal diseases[65,66]. Modes of action of the antibacterial property of thymol appeared to include disruption of bacterial cell membrane integrity by altering protein reactions[67,68]. Also, in greenhouse studies, soil treatment with thymol reduced $R$. solanacearum population in the soil to undetectable levels, and tomato seedlings transplanted into thymol-treated soils did not develop symptoms of bacterial wilt, nor could the pathogen be isolated for at least 4 weeks after inoculation [69].

In general, biological control using microbial antagonists has shown potential as an alternative for natural control of plant pathogens instead of synthetic chemical fungicides $[69,70]$. The mode of action of antagonistic yeasts may be competition for space and nutrients[70,71], production[72], and induction of host resistance[73,74]. In large-scale tests, the use of biological control often needed to be combined with low doses of synthetic fungicides to obtain a level of disease control equivalent to synthetic fungicides[75]. In order to completely eliminate the use of synthetic fungicides, more environmentally friendly and harmless compound (s) should be explored to improve the activity of the antagonist. Selected chemicals such as calcium chloride[36,38], chitosan[76], in combination with biological control agents have been demonstrated to give beneficial effects on control of fruit decay. The control is not total, but in combination with bioactive additives it is possible to obtain the efficacy of the chemical standard[77,78]. Another alternative control method is given by enhancing natural resistance of plants towards the pathogen. Compounds which are triggering plant's own defense mechanisms are termed elicitors. Moreover, the biocontrol activity of $S$. cerevisiae against pathogenic fungi might have possibly resulted from mycoparasitism[79], secretion of lytic enzymes such as $\beta-1,3$ glucanase[80] and production of antibiotics[81].

The present findings demonstrate that plant resistance inducers in combination with bio-agents may have important implications for the future use of antagonistic microorganisms on a commercial scale for controlling such diseases especially under protected cultivation regime.

\section{ACKNOWLEDGEMENTS}

This work was supported financially by the Science and Technology Development Fund (STDF), Egypt, Grant No. 1059.

\section{REFERENCES}

[1] Anonymous, 2009, 'Yearbook of statistics of Ministry of Agriculture.' Agricultural Economical and Statistical Department, Arab Republic of Egypt: Cairo, (2009), [In Arabic]

[2] Kiss, L., 2003, A review of fungal antagonists of powdery mildews and their potential as biocontrol agents. Pest Manage Sci., 59,475-483.

[3] Zhinong, Y., Reddy, M.S., Choong-Min, R.; John A. M.; Wilson, M. and Kloepper, J.W. 2002. Induced Systemic Protection Against Tomato Late Blight Elicited by Plant Growth-Promoting Rhizobacteria. Pytopathology, 92, (12), 1329-1333.

[4] Jagadeesh, K.S., Jagadeesh, D.R., 2009, Biological control of early blight of tomato caused by Alternaria solani as influenced by different delivery methods of Pseudomonas gladioli B25. Acta Horticulture, 808, 327-332.

[5] Chet I, Inbar J and Hadar I. 1997. Fungal antagonists and mycoparasites. In: The Mycota IV: Environmental and Microbial Relationships. Wicklow DT and Soderstorm B, eds. pp 165-184.

[6] Kamilova, F., Validov, S., Lugtenberg, B., 2009, Biological Control of Tomato foot and root rot caused by Fusarium oxysporum f.sp. radicis-lycopersici by Pseudomonas bacteria. Acta Hort. (ISHS), 808,317-320.

[7] Tehrani, S.A., Ramezani, M., 2003, Biological control of Fusarium oxysporum, the causal agent of onion wilt by antagonistic bacteria. Agric. Appl. Biol Sci., 68,(4),543-547.

[8] Dik, A., Wubben, J., Elad, Y., Kohi, J., Shtienberg, D., 2002, Combination of control methods against powdery mildew diseases in glasshouse-grown vegetables and ornamentals. Bull. OIL B-SROP, 25, (10),5-8.

[9] Zinkernagel, V., Tischner, H., Hausladen, H., Habermeyer, H., Taborsky, V., Polak, J., Lebeda, A., Kudela, V., 2002, Practical application of integrated disease management. Plant Prot. Sci., 38, 212-222.

[10] Napier, D., Oosthuyse, S.A., 2000, Use of monopotassium phosphate in the integrated control of powdery mildew. Rivista di Frutticoltura e di Ortofloricoltura, 62, (6), 57-58.

[11] Belanger, R.R., Dik, A.J., Menzies, J.G., 1997, Powdery mildew: Recent advances towards integrated control. In: Boland GS, Kuykendall LD (eds) Plant-microbe interactions and biological control. Marcel Dekker, New York, USA, 
(1997), pp. 89-109.

[12] Reuveni, M., Agapov, V., Reuveni, M., Raviv, M., 1994, Effects of foliar sprays of phosphates on powdery mildew (Sphaerotheca pannosa) of roses. J. Phytopathol. (Berlin), 142, 331-337.

[13] Reuveni, M., Agapov, V., Reuveni, R., 1995, Suppression of cucumber powdery mildew (Sphaerotheca fuliginea) by foliar sprays of phosphate and potassium salts. Plant Pathol. (London), 44, 31-39.

[14] Reuveni, M., Agapov, V., Reuveni, M., 1996, Controlling powdery mildew caused by Sphaerotheca fuliginea in cucumber by foliar sprays of phosphate and potassium salts. Crop Prot., 15, 49-53.

[15] Ziv, O., Zitter, T.A., 1992, Effects of bicarbonates and film forming polymers on cucurbit foliar diseases. Plant Dis., 76, 513-517.

[16] Ziv, O., Hagiladi, A., 1993, Controlling of powdery mildew in Euonymus with polymer coatings and bicarbonate solutions. Hort. Science, 28, 124-126.

[17] El-Mougy, N.S., Abdel-Kader, M.M., 2009, Salts application for suppressing potato early blight. Journal of Plant Protection Research, 49, (4), 353-361.

[18] Mucharromah, E., Kuc, J., 1991, Oxalates and phosphates induce systemic resistance against disease caused by fungi, bacteria and viruses in cucumber. Crop Prot., 10, 265-270.

[19] Yamazaki, H., Hoshima, T., 1995, Calcium nutrition affects resistance of tomato seedlings to bacterial wilt. Hort. Science, 30, 91-93.

[20] El-Mougy, N.S., Abdel-Kader, M.M., Abdel-Kareem, F., Embaby, E.I., El-Mohamady, R., Abd El-Khair, H., 2011, Survey of Fungal Diseases Affecting Some Vegetable Crops and Their Rhizospheric Soilborne Microorganisms Grown under Protected Cultivation System in Egypt. Research Journal of Agriculture and Biological Sciences, 7,(2), 203-211.

[21] SAS, Institute Inc., 'SAS/STAT user's guide. Version 6. Vol. 2.’ 12th edn. (SAS Institute Inc.: Cary, NC), (1996), 846 pp.

[22] Winer, B.J., 'Statistical principles in experimental design.' 2nd edn. (McGraw-Hill Kogakusha Ltd: Tokyo), (1971), 596 pp.

[23] Roinestad, K.S., Montville, T.J., Rosen, J.D., 1993, Inhibition of trichothecene biosynthesis in Fusarium tricinctum by sodium bicarbonate. J. Agric. Food Chem. 41, 2344-2346.

[24] Singh, S.N., Chand, L., 1993, Inhibition of aflatoxin production by garlic extract and sodium bicarbonate. Crop Res., 6, 149-154.

[25] Ashour, A.M.A., 2009, Effect of Application of some Systemic Fungicides and Resistance Inducing Chemicals on Management of Cantaloupe Powdery Mildew Disease. Egypt. J. Phytopathol., 37, (1), 1-8.

[26] Palmer, C.L., Horst, R.K., Langhans, R.W., 1997, Use of bicarbonate to inhibit in vitro colony growth of Botrytis cinerea. Plant Dis., 81, 1432-1438.

[27] Palou, L., Smilanick, J.L., Usall, J., Vinas, I., 2001, Control of postharvest blue and green molds of oranges by hot water, sodium carbonate and sodium bicarbonate. Plant Dis., 85, 371-376.

[28] Qin, G.Z., Tian, S.P., Xu, Y., Chan, Z.L, Li, B.Q., 2006, Combination of antagonistic yeasts with two food additives for control of brown rot caused by Monilinia fructicola on sweet cherry fruit. Journal of Applied Microbiology, 100, 508-515.

[29] Smilanick, J.L., Margosan, D.A., Mlikota, F., Usall, J., Michael, I.F., 1999, Control of citrus green mold by carbonate and bicarbonate salts and the influence of commercial postharvest practices on their efficacy. Plant Dis., 83,139-145.

[30] Wisniewski, M., Wilson, C., El Ghaouth, A., Droby, S., 2001, Increasing the ability of the biocontrol product, Aspire, to control postharvest diseases of apple and peach with the use of additives. Biological control of fungal and bacterial plant pathogens. IOBC/WPRS Bull., 24, (3), 157-160.

[31] Janisiewicz, W.J., Peterson, D.L., 2005, Experimental Bin drenching system for testing biocontrol agents to control postharvest decay of apples. Plant Dis., 89, 487-490.

[32] Petersson, S., Schnurer, J., 1995, Biocontrol of mold growth in high moisture wheat stored under airtight conditions by Pichia anomala, Pichia guilliermondii, and Saccharomyces cerevisiae. Appl. Environ. Microbiol., 61,(3), 1027-1032.

[33] Conway, W.S.0., Sams, C.E., 1985, Influence of fruit maturity on the effect of postharvest calcium treatment on decay of Golden Delicious apples. Plant Disease, 69, 42-44.

[34] Conway, W.S., Abbott, J.A., Bruton, B.D., 1991, Postharvest calcium treatment of apple fruit to provide broad-spectrum protection against postharvest pathogens. Plant Disease, 75, 620-622.

[35] Conway, W.S., Sams, C.E., McGuire, R.G., Kelman, A., 1992, Calcium treatment of apples and potatoes to reduce postharvest decay. Plant Disease, 76, 329-333.

[36] Wisniewski, M., Droby, S., Chalutz, E., Eilam, Y., 1995, Effects of $\mathrm{Ca}^{2+}$ and $\mathrm{Mg}^{2+}$ on Botryris cinerea and Penicillium expansum in vitro and on the biocontrol activity of Candida oleophila. Plant Pathology, 44, 1016-1024.

[37] Saftner, R.A., Conway, W.S., Sams, C.E., 1997, Effects of some polyamine biosynthesis inhibitors and calcium chloride on in vitro growth and decay development in apples caused by Botrytis cinerea and Penicillium expansum. J. Am. Soci. Hort. Sci., 122, 380-385.

[38] Tian, S.P., Fan, Q., Xu, Y., Jiang, A.L., 2002, Effects of calcium chloride on biocontrol activity of yeast antagonists against the postharvest fungal pathogen Rizopus stolonifer. Plant Pathol., 51, 352-358.

[39] Venette, J.R., 1998, Calcium micronutrient may reduce white mold of dry beans. Proceedings of the Sclerotinia Workshop, Minnesota ND, In-Service Extension Worksho, Fargo.

[40] Gulya, T.J., Miller, J.F., 2007, Advances in the development of sunflower germplasm with resistance to both Sclerotinia stalk rot and head rot, and the possible role of calcium in Sclerotinia resistance. Proceedings of the 2007 National Sclerotinia Initiative Annual Meeting, Minneapolis.

[41] Paula Júnior, T.J., Vieira, R.F., Teixeira, H., Carneiro, J.S., 2009, Foliar application of calcium chloride and calcium silicate decreases white mold intensity on dry beans. Tropical 
Plant Pathology, 34, (3), 171-174.

[42] Siegrist, J., Muhlenbeck, S., Buchenauer, H., 1988, b- aminobutyric acid-mediated enhancement of resistance in tobacco to tobacco mosaic virus depends on the accumulation of salicylic acid. Physiol. Mol. Plant Pathol., 53,223-228.

[43] Boyle, C., Walters, D., 2005, Induction of systemic protection against rust infection in broad bean by saccharin: effects on plant growth and development. New Phytol., 167,607-612.

[44] Boyle, C., Walters, D.R., 2006, Saccharin-induced resistance to powdery mildew in barley: effects on growth and phenylpropanoid metabolism. Plant Pathol., 55,82-91.

[45] Trotel-Aziz, P., Couderchet, M., Vernet, G., and Aziz, A., 2006, Chitosan stimulates defense reactions in grapevine leaves and inhibits development of Botrytis cinerea. Eur. J. Plant Pathol., 114,405-413.

[46] Aziz, A., Trotel-Aziz, P., Dhuicq, L., Jeandet, P., Couderchet, M., Vernet, G., 2006, Chitosan Oligomers and Copper Sulfate Induce Grapevine Defense Reactions and Resistance to Gray Mold and Downy Mildew. Phytopathology, 96,1189-1194.

[47] Chang, M.M., Hadwiger, L.A., Horovitz, D., 1992, Molecular characterization of a pea beta-1,3-glucanase induced by $\mathrm{Fu}$ sarium solani and chitosan challenge. Plant Mol. Biol., 20,609-618

[48] Hadwiger, L.A., Tomoya, O., Hiroki, K.H., 1994, Chitosan polymer sizes effective in inducing phytoalexin accumulation and fungal suppression are verified with synthesized oligomers. Mol. Plant-Microbe Interact., 7,531-533.

[49] Hadwiger, L.A., McBride, P.O., 2006, Low-level copper plus chitosan applications provide protection against late blight of potato. Online, Plant Health Progress, doi:10.1094/PHP2006-0406-01-RS.

[50] Atia, M.M.M., Buchenauer, H., Aly, A.Z., Abou-Ziad, M.I., 2005, Antifungal activity of chitosan against Phytophthora infestans and activation of defence mechanisms in tomato to late blight. Biological agriculture \& horticulture, 23, 175-197.

[51] Chircov, S.N., 2002, The antiviral activity of chitosan (review). Applied Biochemistry and Microbiology, 38, 1-8.

[52] Rabea, E.I., Badawy, M.E.I., Stevens, C.V., Smagghe, G., Steurbaut, W., 2003, Chitosan as antimicrobial agent: applications and mode of action. Bio macro molecules, 4, 1457-1465.

[53] Zheng, L., Zhu, J., 2003, Study on antimicrobial activity of chitosan with different molecular weights. Carbohydrate Polymer, 54, 527-30.

[54] Scheuerell, S.J., Mahaffee, W.H., 2006, Variability Associated with Suppression of Gray Mold (Botrytis cinerea) on Geranium by Foliar Applications of Nonaerated and Aerated Compost Teas. Plant Dis., 90, 1201-1208.

[55] Abd-El-Kareem, F., 2007, Induced resistance in bean plants against root rot and Alternaria leaf spot diseases using biotic and abiotic inducers under field conditions. Research $\mathrm{J}$. Agricultural and Biological Science, 3,(6), 767-774.

[56] Atiyeh, R.M., Lee, S., Edwards, C.A., Arancon, N.Q., Metzger, J.D., 2002, The influence of humic acids derived from earthworm processed organic wastes on plant growth.
Bioresource Technology, 84, 7-14.

[57] Chen, Y., Nobili and T. Aviad, 2004. Stimulatory effect of humic substances on plant growth. In "Soil organic matter in sustainable agriculture". (Eds F. Magdoff, R.R. Weil), 103-130, Boca Raton, FL. Dewis, J. and F. Freitas, (1970), "Physical and chemical methods of soil and water and analsis " food and agriculture organization of United Nations, Rome.

[58] Piccolo, A., Nardi, S., Concheri, G., 1992, Structural characteristics of humic substances as regulated to nitrate uptake and growth regulation in plant systems. Soil Biochem., 24, 373-380.

[59] Zhang, X., 1997, Influence of plant growth regulators on turfgrasss growth, antioxidant status, and drought tolerance. Ph.D. thesis, Fac. Of Virginia Polytechni (Institute and State University).

[60] Ziadi, S., Barbedette, S., Godard, J.F., Monoti, C., Corre, L.E.D., Silue, D., D. Lecorre, 2001, Production of pathogenesis related protein in the cauliflower (Brassica oleacea var. botrytis) downy mildew (Peronospora parasistica) pathosystem treated with acidbenzolar-5-methyl. Plant Pathol., 50, (5), 579-586.

[61] Dmitrier, A., Tena, M., Jorrin, J., 2003, Systemic acyuired resistance in sunflower (Helianthus annuus L.). Tsitologiya-1-Genetika, 37,(3), 9-15.

[62] Achuo, E.A., Audenaert, K., Meziana, H., Hofte, M., 2004, The salicylic acid dependent defence pathway is effective against different fungi in tomato and tobacco. Plant Pathol., $53,65-72$.

[63] Yang, V.W., Clausen, C.A., 2007, Antifungal effect of essential oils on southern yellow pine. International Biodeterioration \& Biodegradation, 59, 302-306.

[64] Momol, M.T., Olson, S.M., Pradhanang, P.M., Jones, J.B., 2005, Evaluation of thymol as biofumigant for control of bacterial wilt of tomato under field conditions. Plant Dis., 89,497-500.

[65] Paster, N., Menasherov, M., Ravid, U., Juven, B., 1995, Antifungal activity of oregano and thyme essential oils applied as fumigants against fungi attacking stored grain. J. Food Prot., 58,81-85.

[66] Liu, W.T., Chu, C.L., Zhou, T., 2002, Thymol and acetic acid vapors reduce postharvest brown rot of apricots and plums. Hort. Science, 37,151-156.

[67] Juven, B.J., Kanner, J., Schved, F., Weisslowicz, H., 1994, Factors that interact with the antibacterial action of thyme essential oil and its active constituents. J. Appl. Bacteriol., 76, 626-631.

[68] Walsh, S. E., Maillard, J.Y., Russell, A.D., Catrenich, C.E., Charbonneau, D.L., Bartolo, R.G., 2003, Activity and mechanisms of action of selected biocidal agents on Gram positive and negative bacteria. J. Appl. Microbiol., 94,240-247.

[69] Pradhanang, P.M., Momol, M.T., Olson, S.M., Jones, J.B., 2003, Effects of plant essential oils on Ralstonia solanacearum population density and bacterial wilt incidence in tomato. Plant Dis., 87,423-427.

[70] Droby, S., Chalutz, E., Wilson, C.L., Wisniewski, M., 1989, Characterization of the biocontrol activity of Debaryomyces hansenii in the control of Penicillium digitatum of grapefruit. 
Can. J. Microbiol., 35, 794-800.

[71] Janisiewicz, W.J., Tworkoski, T.J., Sharer, C., 2000. Characterizing the mechanism of biological control of postharvest diseases on fruits with a simple method to study competition for nutrients. Phytopathology, 90, 1196-1200.

[72] El-Ghaouth, A., Wilson, C.L., Wisniewski, M., 1998, Ultrastructural and cytochemical aspects of the biological control of Botrytis cinerea by Candida saitoana in apple fruit. Phytopathology, 88, 282-291.

[73] Arras, G., 1996, Mode of action of an isolate of Candida famata in biological control of Penicillium digitatum in orange fruits. Postharvest. Biol. Technol., 8, 191-198.

[74] Droby, S., Vinokur, V., Weiss, B., Cohen, L., Daus, A., Goldschmidt, E.E., Porat, R., 2002, Induction of resistance to Penicillium digitatum in grapefruit by the yeast biocontrol agent Candida oleophila. Phytopathology, 92, 393-399.

[75] Droby, S., Wisniewski, M., El-Ghaouth, A., Wilson, C., 2003, Influence of food additives on the control of postharvest rots of apple and peach and efficacy of the yeast based biocontrol product Aspire. Postharvest Biol. Technol., 27,127-135.

[76] El-Ghaouth, A., Smilanick, J.L., Brown, G.E., Ippolito, A., Wisniewski, M., Wilson, C.L., 2000, Applications of Can- dida saitoana and glycolchitosan for the control of postharvest diseases of apple and citrus fruit under semi- commercial conditions. Plant Dis., 84, 243-248.

[77] Lima G., Castoria R., Spina A.M., De Curtis, F., 2005, Improvement of biocontrol yeast activity against postharvest pathogens: recent experiences. Acta Hortic., 682, 2035-2040.

[78] Conway, W.S., Leverentz, B., Janisiewicz, W.J., Saftner, R.A., Camp, M.J., 2005, Improving biocontrol using antagonist mixtures with heat and/or sodium bicarbonate to control postharvest decay of apple fruit. Postharvest Biol. Technol., 36, (3), 235-244.

[79] Hajlaoui, M.R., Belanger, R.R., 1993, Antagonism of the yeast like phylloplane fungus Sporothrix flocculosa against Erysiphe graminis var tritici. Biocontrol Sci. Technol., 11, 427-434.

[80] Punja, Z.K., 1997, Comparative efficacy of bacteria, fungi and yeasts as biological control agents for disease of vegetable crops. Can. J. Plant Pathol., 19, 35-323.

[81] Benyagoub, M., Rhlid, R.B., Belanger, R.R., 1996, Purification and characterization of new fatty acids with antibiotic activity produced by Sporothrix flocculosa. J. Chem. Ecol., 22, 405-413. 